\title{
Rates of Return on Physical and Human Capital in Africa's Manufacturing Sector
}

\author{
Arne Bigsten $^{(1)}$, Paul Collier ${ }^{(2)}$, Stefan Dercon ${ }^{(3)}$, Marcel Fafchamps ${ }^{(4)}$, \\ Bernard Gauthier $^{(5)}$, Jan Willem Gunning ${ }^{(6)}$, Anders Isaksson ${ }^{(1)}$, Abena \\ Oduro $^{(7)}$, Remco Oostendorp ${ }^{(6)}$, Cathy Pattillo ${ }^{(8)}$, Mans Soderbom ${ }^{(1)}$, \\ Francis Teal $^{(2)}$, Albert Zeufack ${ }^{(9)}$
}

WPS/98-12

\author{
May 1998 \\ Centre for the Study of African Economies \\ Institute of Economics and Statistics \\ University of Oxford \\ St Cross Building \\ Manor Road \\ Oxford OX1 3UL
}

\begin{abstract}
${ }^{(1)}$ Göteborg University, ${ }^{(2)}$ University of Oxford, ${ }^{(3)}$ University of Oxford and Katholieke Universiteit Leuven, ${ }^{(4)}$ Stanford University, ${ }^{(5)}$ École des Hautes Études Commerciales, Montréal, ${ }^{(6)}$ Free University, Amsterdam, ${ }^{(7)}$ University of Ghana, Legon, ${ }^{(8)}$ Research Department, IMF, ${ }^{(9)}$ World Bank. The authors are members of the ISA (Industrial Surveys in Africa) group which uses multi-country panel datasets to analyse the microeconomics of industrial performance in Africa.
\end{abstract}

JEL Classifications: I21, J31, O55.

Key words: investment, human capital, African manufacturing

Correspondence: Dr F J Teal, Centre for the Study of African Economies.

E-mail: francis.teal@economics.oxford.ac.uk.

This paper draws on work undertaken as part of the Regional Programme on Enterprise Development (RPED), organised by the World Bank and funded by the Swedish, French, Belgian, UK, Canadian and Dutch governments. Support of the Dutch and UK governments for workshops of the group is gratefully acknowledged. Simon Appleton and Geeta Kingdon have been generous with their time in answering questions. John Knight and Lina Song have been very helpful in enabling comparisons to be made between their data from Chinese enterprises and that used in this paper. The use of the data and the responsibility for the views expressed are those of the authors.

\footnotetext{
Abstract: In this paper two sets of issues are addressed using panel data from the manufacturing sector of five African countries. First, how high are the returns to human relative to physical capital. Second, what is the relative importance of technology and endowments of human and physical capital in determining differences in earnings and productivity across the countries. Evidence from earnings functions shows that the private returns to both experience and education rise with the level of education. Private returns rise from 3 per cent at the primary level, to 10 per cent at the secondary level and 35 per cent for tertiary. Evidence from the production function gives lower returns on education than from the earnings function. Rates of return on physical capital exceed 20 per cent and greatly exceed the average return on human capital. Data is available on the stocks of human and physical capital across the countries. Productivity and earnings differentials are shown to be large between Cameroon and Ghana. These differences are due almost entirely to differences in physical, not human, capital endowments.
} 



\section{Introduction}

In this paper four policy questions are addressed for five sub-Saharan African countries; the Cameroon, Ghana, Kenya, Zambia and Zimbabwe. First, how have real wages changed in the early 1990s? Second, what are the rates of return on human capital across these countries? Third, how do the rates of return on human and physical capital differ? Fourth, can the differences in labour productivity in the firms and the earnings of workers, across the five countries, be better explained by technology, or by the human capital characteristics of the workers, or by the amount of physical capital per employee in the firm?

Rates of return on human capital in sub-Saharan Africa have been extensively investigated - a recent survey is in Appleton, Hoddinott and Mackinnon (1996). The extension in this paper, to a comparison between the returns on both human and physical capital, is made possible by the use of data which allows information on worker's education, and other human capital characteristics, to be combined with firm level information on physical capital and labour inputs. The international comparison is possible as similar data was collected for manufacturing enterprises in five sub-Saharan Africa countries over the same period. The size range of these enterprises is very large. The smallest in the sample had one employee, the largest over three thousand. The sample allows comparisons to be made across a much wider size range of enterprises than is possible with some other datasets.

It has been widely argued that human, rather than physical, capital is the major determinant of income differences across countries, Lucas ( 1988, 1990), Romer (1996). Krueger (1968) and Fallon and Layard (1975) provide conflicting empirical estimates of the relative importance of physical and human capital based on macro data. In this paper a narrower, and microeconomic, focus is taken to that question. It is narrower in that the focus is on the manufacturing sector. It is well known that in explaining long run income differences across countries changes in sectoral allocation are of major importance. It is microeconomic in that the data is drawn from surveys of manufacturing enterprises. While the focus is on micro manufacturing data the question addressed is identical to that posed at the macro level: how can differences in returns to factors across countries be explained?

A much highlighted difference between sub-Saharan Africa and the successful NICs has been the lack of manufacturing exports in the former and their rapid growth in the latter. It has been argued that the underlying cause of the lack of exports of manufacturing from African economies is that the relative scarcity of skilled labour in Africa ensures that Africa has a comparative advantage in natural resource exports, Wood (1994), Wood and Berge (1997) . This argument has recently been extended from a narrow definition of manufactures to one which includes the processing of primary products within a definition of manufacturing, Owens and Wood (1997). If skilled labour is scarce then an implication would seem to be that the returns to skilled labour in Africa should be relatively high. It is inferences of this form that are the basis for the view that expanding educational provision is a requirement for a successful programme to accelerate growth in sub-Saharan African economies.

The view that the return to education in sub-Saharan Africa is high has recently been challenged by Bennell (1996). The most recent of the surveys of the evidence by Psacharopoulos (1994) finds that the rate of return on primary education was 24 per cent, for secondary education it was 18 and for higher education 11 per cent. Bennell argues that "the conventional rate of return on education patterns almost certainly do not prevail in sub-Saharan Africa under current labour market conditions." (p.195) That this objection is possibly correct is suggested by the survey of the Mincerian returns to education in sub-Saharan Africa in Appleton, Hoddinott and Mackinnon (1996) who show that there is a general pattern by which the returns to education rise 
with its level. The average returns to education suggested by their survey are substantially below those presented in Psacharopoulos (1994). These two sets of arguments present a puzzle. Why, if skilled labour is relatively scarce, is not the return to education high?

This paper investigates the questions posed by two routes. First, by using an earning functions on the individual level data and, second, by using a production function incorporating both physical and human capital. Section 2 summarises the data on real wages by education across the five countries. The returns to education from an earnings function are considered for each country in section 3 and possible biases in the results discussed. The modelling of both human and physical capital in the production function is taken up in section 4, again for each country. In section 5 the data is pooled across the countries so that the size of underlying productivity differentials across the countries can be assessed as can the relationship between productivity and earnings. A final section summarises the argument and provides conclusions.

\section{Real wages, Education and Physical Capital}

The data on which the paper draws was collected over three years for a panel of firms within the manufacturing sectors of the Cameroon, Ghana, Kenya, Zambia and Zimbabwe. The sectors within the manufacturing sector were chosen so as to be as similar as possible across the countries. At the same time as the firms were surveyed a parallel interview was carried out for a representative sample of the workers in the enterprises. It is therefore possible to match the characteristics of workers in the firm with the levels of physical capital, labour inputs and output of the enterprises in which they work.

Table 1 presents the earnings of all workers across the three waves of the data for the five countries. For comparative purposes we provide, at the bottom of the table, the evidence for earnings from a survey of enterprises in China carried out at the same time as the African surveys. Table 1 provides four measures of the earnings of workers in the enterprises. The first two convert the domestic currency to US dollars the first using the nominal exchange rate and the second using a purchasing power parity (PPP) rate. The third measure is a domestic currency units measure of nominal wages. The final measure is a constant price series to see how, when nominal wages are deflated by the domestic consumer price index, real wages are changing in domestic currency terms.

The range of wages across the five countries is high. The PPP monthly wage in Cameroon at US \$467 was nearly three times that in Ghana at US \$170. Average wages in Kenya and Zimbabwe were virtually identical over the period of the survey, while those in Zambia were very similar to those in Ghana. The purchasing power parity value of wages in both Zambia and Ghana are substantially below those in China.

What of changes over time? Real wages in domestic currency stagnated or fell over the survey rounds in all the countries except Kenya. In the Cameroon and Zambia these falls appear to have been substantial, of approximately 30 per cent. However, it is necessary to control for possible changes in the composition of the sample over the survey rounds so we will return to the issue of changes in real wages when an earnings function is presented below.

The comparisons presented in Table 1 are extended in Table 2 to see how far the large differences remain for workers of a similar educational status. In the comparison the omitted category is those who failed to complete primary education. ${ }^{1}$ We compare this base category with,

\footnotetext{
1 This choice was forced on us as the data for Ghana did not allow us to identify those who started, but failed to complete, primary school.
} 
first, primary completed, second, secondary completed and finally, those who completed university. In Table 2 the data is presented for the estimates of the number of years of education each of these stages took and the earnings, using PPP exchange rates, for each educational category by country.

There are two ways of measuring years of education from the data. One, termed formal in the table, uses the answers to the questions of level, and form, reached to infer the number of years. As forms can be repeated such a procedure provides a minimum estimate of the number of years of education. The second way of measuring years of education, termed actual in Table 2, is to assume education began at the age of 6 and then use the information on the year full time education ceased to infer years of education. As many children do not start education at 6 this method provides an estimate with opposite errors to the first method. For secondary and university completers the two methods give similar averages. For lower education levels the "actual" figures are in some cases substantially higher than the "formal" figures. The table presents earnings in US PPP dollars. At the university level there is a very narrow range for three of the countries, Cameroon, Kenya and Zimbabwe. It will be noted that the relatively high earnings in the Cameroon are due to much higher wages for secondary completers in that country than for the others. The low wages in Zambia relative to Ghana are due to the very low wages paid to both primary completers and non-completers in that country.

The overall average, for years of education shown in Table 2, is 9.8 and the range across the countries is very small: from 9.5 years in Zimbabwe to 11.6 years in the Cameroon. If differences in human capital are to explain the differences in wages then this measure must hide either differences in composition, differences in returns or differences in quality; or some combination of all three. If earnings for a given skill level differ across the countries these differences will be reflected in differing endowments of capital per worker. The potential importance of this factor is brought out in Table 3 which extends Table 2 by showing the physical and human capital characteristics of the firms.

While the years of education are similar across the countries the proportion of the work force who had completed secondary education ranged from 16 per cent in Ghana to 40 per cent in the Cameroon. Ghana's workforce is dominated by primary school completers while that of the other countries is dominated by secondary school completers. There are also very large differences across the countries in the size and capital intensity of the firms. The Zimbabwe sample has by far the largest firms, an average 300 employees, as compared with only 42 in the Ghana sample. The differences in capital per employee are also large with Ghana, again, far below the other countries. The Ghanaian firms are smaller, have less than a third of the capital per employee of firms in the other countries, and a less educated work force. ${ }^{2}$ The question posed in the introduction is how far these differences can explain productivity and earnings differentials. To answer that question we must consider how to model these outcomes.

\section{Returns to Human Capital from the Earnings Function}

In Table 4 we present an earnings functions with the human capital variables that we have for all five countries. Education is measured by the level of formal education completed. Experience is measured by age and firm specific learning is measured by the tenure of the worker in their current

\footnotetext{
2 It will be noted that the value-added per employee figure for Zambia is very low. This is probably due to problems in the use of PPP exchange rates to convert the domestic Zambian currency to US dollars. Zambia experienced a period of very high rates of inflation in the early 1990s and it is possible the PPP exchange rate is misleading over the period. The data appendix gives the PPPs used in the calculations.
} 
job. These experience variables are modelled with a quadratic term to allow for the expected nonlinearities in the effects of experience on earnings. With the exception of the quadratic term on tenure all the variables are highly significant. There are highly significant differences across the countries. It is possible to use the earning function estimates to assess how real wage have changed over time, when possible differences in the sample are controlled for, and to estimate the returns to education. There are numerous reasons, which we consider below, why the estimates in the earnings functions may be biased.

First we set out the implied changes in real wages across the survey period for each of the countries. The change vary from a rise of 18 per cent in Kenya to a fall of 40 per cent in the Cameroon. ${ }^{3}$ This latter figure is higher than that obtained from the raw data and shows the importance of controlling for differing characteristics over the course of the surveys. The earnings function for the Cameroon implies that in a period when inflation was above 30 per cent per annum, nominal wages fell by about 7 per cent. The second largest fall in real wages was in Zambia where large rises in nominal wages were insufficient to compensate for continuing high inflation. In contrast there was a rise of 18 per cent in real wages in Kenya.

The returns to both education and experience can be inferred from Table 4 . The ageearning profiles across three of the countries - the Cameroon, Zambia and Zimbabwe - are very similar, with Ghana and Kenya being contrasting outliers. Ghana has a particularly steep ageearnings profile while the one in Kenya is much flatter than the average across the countries. The returns to education can be calculated in two ways. First it is possible to use the coefficient on the dummy variable for the level of education completed as one measure on the return to education. Such a measure takes no account of the number of years taken to complete the level and, if used to measure the rate of return, implicitly assumes that the foregone opportunity cost over those years was zero. We present the measure as a maximum number for the rate of return on education. A second way of measuring returns is that proposed originally by Mincer (1974). The assumption which underlies the Mincerian interpretation is that, for each educational level, the foregone opportunity cost is the wage which would have been obtained with the education level the one below the one completed. This calculation can be viewed as a minimum for the estimated rate of return. We continue to abstract from the possibility of bias in the coefficients. In Table 5 we present the returns to education implied by both these methods of calculation. The increment in earnings shown in the Table 5 is, for each educational level, the percentage increase in earnings that accrues from completing that level of education calculated from the earnings function of Table 4. The years of education are taken from the formal education figures in Table 2. Rates of return are then simply the increment in earnings divided by the number of years it took to acquire the increment.

Whichever method is chosen the pattern is the same across all the countries. Private rates of return to education rise with the level of education. For university completers it is clear that the assumption that underlies the maximum calculation is false. However, it is true for all countries that the returns to university education using the Mincerian assumption are greater than the returns to primary education using the maximum assumption, where it is much more reasonable. Have we here the answer to the puzzle we posed in the introduction? Why, if skilled labour in Africa is scarce, are not the returns to skilled labour high? If by skilled labour is meant secondary school completion, and beyond, then the return to skilled labour is high.

3 The increment in nominal earnings are obtained from the dummy variables as exp(coefficient) -1 as suggested by Halvorsen and Palmquist (1980). These are then deflated by the rise in the price index given at the bottom of Table 4 to obtain the change in real wages. 
There are several reasons why the returns to education presented in Table 5 may be based on coefficients that are biased. Bias may arise as we have not allowed for selectivity. Those who work in the manufacturing sector are highly atypical. Such selectivity bias may not simply mean that the returns to education are overstated, our sample excludes all those who completed education and did not get employed in manufacturing, but may bias the estimates so obtained for those who did get employed. Secondly, such educational measures cannot distinguish between signalling and credentionalism as alternatives to the human capital interpretation. Thirdly, it is known that parental background can play an important role in educational choice. Our sample is limited to those in manufacturing, we have no variables measuring ability or information on parental background. The question we wish to pose is the following: if no controls are included for cognitive skills or parental background is there evidence of significant bias up or down in the interpretation of the crudely measured education variable?

A recent study examining some of these issues for Ghana is Glewwe (1996) who provides evidence that there may be an upward bias. If selectivity is allowed for in the private sector earnings function for his data then the coefficient on years of schooling becomes insignificant. Glewwe then calculates the rate of return on education based on the measures of cognitive skills available for his data set. He finds a figures of 4 per cent, for an individual aged 25, which compares with a rate of return of 7 per cent from the OLS earning function.

Five studies which have information on parental background are, Behrman and Wolfe (1983), Lan and Schoeni (1993), Heckman and Hotz (1986), Krishnan (1996) and Kingdon (1997). The conclusion, which is uniform across the studies, is that the inclusion of parental background reduces the returns to schooling by about 20 per cent. Krishnan (1996) has recent African evidence from Ethiopia and obtains a similar result to earlier studies. Her study shows that this effect is due almost entirely to the effects of parental background on access to education. Once the selectivity bias was controlled for the effects from parental background onto returns was small. All this evidence suggests that the estimates presented in this paper from the earnings function may be upwardly biased. A recent study which uses a panel data set of twins to estimate the returns to school quality, Behrman, Rosenzweig and Taubman (1996) finds that controlling for family background does affect the assessment of the returns from school quality but has only very marginal effects on the returns to schooling coefficient. A study which has very detailed information on cognitive skills and parental background is that of Knight and Sabot (1990). Their study uses comparative data drawn from workers in the manufacturing sector of Kenya and Tanzania. They argue that the returns of education variable is picking up human capital formation. While signalling may play some role, it is not the primary reason years of education determines earnings.

The conclusion we would draw is that the evidence suggests that the education variable will overstate the returns to human capital and that the major influence of years of education on earnings is through its effects on cognitive skills and not, as the signalling explanation would imply, indirectly through signalling ability. Even if the biases are more significant that the empirical evidence currently suggests, it is not clear that they would explain, or mitigate, the nonlinearity in the returns to education.

Education is only one dimension of human capital. Freeman (1986, p.377) notes that "every study also finds that, by itself, years of schooling explains a relatively small part of the variance of log earnings, say 3-5 percent at most". It is possible that it is the link between education and returns to experience and training where substantial increases in earning/productivity might be possible. In the earnings function such returns can be measured from the age variable as a proxy for experience. In the production functions of the next section 
it will be shown that tenure captures an important aspect of human capital in the production process for some of our countries.

The returns from work experience, in which the age variable in the earnings function is interpreted as returns to learning, are reported in the bottom part of Table 5. The rate of return is calculated by asking the average annual increase in earnings for a worker of a given educational level over a twenty year period, of which the middle is the average age of workers in that category. The pattern is that which has been observed in other datasets of this form. The returns to experience rise with educational level. The returns to experience are largest, for both primary and secondary completers, for Ghana. In all the countries, except Ghana, the weighted average of the return from experience is lower than that for education, Table 5. In the next section we consider how these returns compare with those for physical capital from using a production function.

\section{Human and Physical Capital in Production}

The data presented in this paper enables a comparison to be made between the returns from human capital investment with those on physical capital in a production function. It is the existence of the firm level data that makes such a comparison possible. The discussion is clearest if a simple Cobb-Douglas form of the production function is assumed:

[1] $\quad \operatorname{Ln} Y_{\mathrm{ijt}}=\beta_{0 \mathrm{j}}+\beta_{1} \operatorname{Ln} \mathrm{L}_{\mathrm{ijt}}+\beta_{2} \operatorname{Ln} \mathrm{K}_{\mathrm{ijt}}+\beta_{3} \operatorname{Ln} \mathrm{H}_{\mathrm{ijt}}+$ controls $+\mathrm{u}_{\mathrm{ijt}}$ where $\mathrm{Y}$ is output, $\mathrm{L}$ is labour input, $\mathrm{K}$ is physical capital and $\mathrm{H}$ is human capital. The subscripts denote the $i_{\text {th }}$ firm, in the $j_{\mathrm{th}}$ country at time $t$. The dimensions of human capital that can be measured from the survey are the level of education completed, the number of years of education, experience measured by age and the tenure of workers in the firm.

The variables $\mathrm{Y}, \mathrm{L}$ and $\mathrm{K}$ are measured at the firm level. The human capital variables are based on the individual data and are averaged across the firm to produce an estimate of the firm level composition of these dimensions of human capital. Real wages and the returns to capital are given by the marginal productivity relationship so:

[2] $\mathrm{w}_{\mathrm{ijt}}=\beta_{1} \mathrm{Y}_{\mathrm{ij \textrm {t }}} / \mathrm{L}_{\mathrm{ijt}}$ and $\mathrm{r}_{\mathrm{ijt}}^{\mathrm{s}}=\beta_{2} \mathrm{Y}_{\mathrm{ijj}} / \mathrm{K}_{\mathrm{ijt} \text {. }}$ The returns to human capital in a form commensurate with that for physical capital can be obtained from:

[3] $\quad \mathrm{r}_{\mathrm{ijt}}^{\mathrm{H}}=\left(\mathrm{dY}_{\mathrm{ijt}} / \mathrm{Y}_{\mathrm{ijt}}\right) / \mathrm{dH}_{\mathrm{ijt}}=\beta_{3} / \mathrm{H}_{\mathrm{ijt}}$.

Equation [1] sets out the form of the production function which is estimated for each country and presented in Tables 6 and 7 which differ by how human capital is measured. In Table 6 the Education variables used in the regressions in the total years of education in the firms,

[4] Education $=\mathrm{E} \times \mathrm{L}$.

In Table 7 human capital is measured by also including total years of tenure ( $\mathrm{T} \times \mathrm{L}$ ) in the firm where tenure is defined as the length spent in the current job,

[5] Human Capital $(\mathrm{H})=\mathrm{E} \times \mathrm{L}+\mathrm{T} \times \mathrm{L}$.

We also experimented with including age as a measure of experience and for no country was that variable superior to the measure of human capital in [5] and for some countries it produced negative coefficients on the age variable. We infer that, at the firm level, the average age of the workforce is an inferior measure of human capital to tenure. In assessing the relative importance of physical and human capital in the inter-country determinants of earnings and productivity it is necessary to aggregate equation [1] across countries which gives, assuming constant returns to scale, 
At the country level the link between earnings an productivity is given by:

[7]

$$
\begin{aligned}
\operatorname{Ln~}_{\mathrm{jt}} & =\operatorname{Ln} \beta_{1}+\operatorname{LnY}_{\mathrm{jt}} / \mathrm{L}_{\mathrm{jt}} \\
& =\quad \text { Constant }+\beta_{2} \operatorname{Ln~} \mathrm{K}_{\mathrm{jt}} / \mathrm{L}_{\mathrm{jt}} \beta_{3} \operatorname{Ln~} \mathrm{H}_{\mathrm{jt}} / \mathrm{L}_{\mathrm{jt}}+\text { controls }+\mathrm{u}_{\mathrm{jt}} .
\end{aligned}
$$

Under the competitive market assumptions differences in labour productivity across countries will be matched by differences in earnings. At the country level the causality, in fact, runs from earnings to the capital labour ratio to productivity. Productivity differences will reflect differences in technology, the country shift parameter in the production function $\left(\beta_{0 j}\right)$, and differences in physical and human capital endowments. The micro analogue to the macro questions posed in the papers by Krueger (1968) and Fallon and Layard (1975) is the respective roles of technology and physical and human capital endowments across countries in determining differences in productivity and earnings.

We take up below the comparison of the productivity relationship and earnings functions across countries. First we present the estimates for equation [1] in Tables 6 and 7 for each of the countries. In modelling the production decision of the firm we exploit the panel dimension of the firm data to make both physical and human capital predetermined variables. Employment in the current period is instrumented by lagged employment. In Table 6 human capital is simply the total years of education of workers in the firm. We have used the continuous measure of eduction as that enables us to set up a translog production function to test the restrictions implied by the use of the Cobb-Douglas form. In both Tables 6 and 7 a test is reported on the move from the general translog to the Cobb-Douglas specification. The restrictions are accepted for all the countries. A test is also reported for restricting returns to scale to unity and this is rejected at the 1 per cent level in the Cameroon and Zimbabwe, but accepted in the other countries. In Table 7 a test is also reported of restricting the coefficient on the two aspects of human capital, education and tenure, to be the same. This restriction is accepted for all countries. It is clear from a comparison of Tables 6 and 7 that for the Cameroon and Ghana the wider definition of human capital is a more significant determinant of output, but for the other countries it makes little difference which measure of human capital is used. At the bottom of the tables we report the implied rates of return for physical and human capital for both specifications of the measure of human capital. The rate of return on physical capital is obtained by taking the median value-added to capital ratio given in Table 3 and multiplying it by the coefficient on the physical capital stock variable in the production function. The rate of return on human capital is obtained from using equation [3] above. For all countries, and whichever measure of human capital is used, the returns on physical capital massively exceed those on human capital.

A comparison of Tables 5 and 6 shows that, with the exception of Kenya, the returns on education as a measure of human capital from the earnings function exceed those from the production function. This finding is consistent with the summary presented above that the earnings function will, in the form presented in Table 4, overstate the returns on education. The high rates of return on physical capital are not reflected in high investment by the firms, Bigsten et al (1998). They argue that the implication of the co-existence of high marginal productivities and low investment is that the cost of capital to the firms is high.

\section{The Determinants of Productivity and Earnings across Countries}

In Table 8 we pool the earnings functions across the countries using the PPP valuation of earnings. It is clear from the highly significant, and large, country dummies in these regressions that differing human capital characteristics explain only a small part of the earning differentials across the countries. Table 8 equation [2] uses firm level controls to see if these explain the 
country effects. While the inclusion of the controls lowers the returns on education they have no impact on the country dummies. In Table 9 a calculation is presented as to the implied average return on education across the five countries. The figure is a weighted average across the three categories of educated labour identified in the earnings function. Without controls the returns to education is 9 per cent, with controls it is 7 per cent. We now turn to a comparison between this result and that using the production functions.

In Table 10 we pool the production functions across countries using both measures of human capital. For both regressions the hypothesis of common coefficients across the countries is accepted at the 1 per cent significance level. In comparing the two regressions in Table 10 it is clear that the wider definition of human capital in equation [2] reduces the size of the country dummies. Cameroon, Kenya and Zimbabwe now pool with Ghana having a technology about 25 per cent less efficient than that of the other countries and Zambia a highly significant outlier among the countries. We report in the table the rates of return on physical and human capital across the pooled sample. It will be noted that for both regressions the hypothesis of constant returns to scale is rejected at the 1 per cent significance level. If this constraint is relaxed the returns on eduction halve so the imposition of the restraint is acting to increase the returns to human capital.

Finally in Table 11 we turn to the determinants of productivity and earnings. In Table 11 equation [1] we reproduce the result in Table 10 equation [2] but now presented in terms of the productivity of labour in the firm. The determinants of productivity can be compared directly with those of earnings. The terms in human capital are virtually identical between the two equations. ${ }^{4}$ As noted above, if we move to a country based regression, then the coefficient on the capital labour ratio in the earnings function should rise in principle to the same value as characterises the production function. The level of aggregation leaves very few degrees of freedom but the result shown in Table 11, equations [3] and [4], is broadly consistent with these expectations with the coefficient on the log of the capital labour ratio rising from 0.08 to 0.19 , close to the value of 0.28 from the productivity equation, Table 11 equation [1]. The coefficient on the human capital term for both the productivity and the earnings equation rises substantially when we aggregate across countries which may capture externalities or may simply reflect the lack of variation of this variable across the countries.

We can now ask what are the factors determining differences in productivity and earnings across the five countries. The factors determining differences in productivity can be directly inferred from Table 11, equation [1]. With the exception of Zambia, which we have already noted may reflect problems with the measurement of the PPP exchange rates, differences in technology play a small part. There are no significant differences in the underlying production function for the Cameroon, Kenya and Zimbabwe. The technology in Ghana is 30 per cent less efficient. In the data from Table 3 the gap in median labour productivity between the Cameroon and Ghana was 3.7 times. All but 25 per cent of this difference is explained by differences in physical and human capital endowments. Again from Table 3 we note that the differences in human capital endowments are modest, 12 per cent using the definition of human capital which combines both years of education and tenure in the firm. In contrast the differential in median physical capital endowments was 14 times. Using the production function shown in Table 11 such a differential in physical capital per employee implies a 3.7 differential in labour productivity, exactly as shown

This result for Ghana was first noted by Jones (1994). 
in the data. It is clear that virtually all the differences in productivity between the manufacturing sectors in the Cameroon and Ghana are explained by differences in physical capital endowments.

As noted above, under the competitive market assumptions, the differences in labour productivity should be reflected in differences in earnings. Thus the earnings differential between the Cameroon and Ghana should be 3.7 times. In fact it is less. In Table 1, based on the individual data, the differential is 2.7 times, while in Table 3, based on the firm level data, it is 2 times. There are two possible explanations for the low level of this earning differential between the two countries. First, it may be due to problems in the use of PPP exchange rates. Using official exchange rates the earnings differentials across the countries is much larger, 5.4 times. Second, it is possible that earnings do not exactly reflect differences in productivity as the labour market is not competitive. Whatever the explanation for the failure of earnings to reflect productivity differences across the two countries the small difference in human capital, which have been documented, imply that such differences cannot play a significant part in explaining differences in either productivity or earnings.

\section{Summary and Conclusions}

We now summarise our answers to the four questions posed at the beginning of this paper. The answer to the first is that only in one country, Kenya, did the real wage rise in the early 1990s. Real wages stagnated in Zimbabwe and fell in Zambia, Ghana and the Cameroon. The fall in real wages in the Cameroon was particularly large at 40 per cent. By the end of the survey periods three countries, Zimbabwe, Kenya and the Cameroon, had very similar wages in purchasing power parity terms of about US\$ 350 per month. Such wage levels are comparable to those found in Chinese rural enterprises. In the case of both Zambia and Ghana wages are substantially lower at about US\$170 per month. The issue that we have addressed is whether, within these averages, the relative wage of skilled workers in Africa is high.

It was to that issue that our second question was addressed: what are the rates of return on human capital in Africa? The data used in this paper allows a comparison to be made between the answer to that question from earnings functions and from the use of a measure of human capital in the production function. The rate of return on average for education, across the five countries, from the earnings function was 9 per cent. The returns were highly non-linear rising from 3 per cent for primary to 14 per cent for secondary completers and 43 per cent for university completers. It has been widely argued that these estimates overstate the return to human capital. Our use of a production function to measure the return supports such arguments; the rate of return on human capital measured by years of education from the production function was 5 per cent, again on average across all the five countries. The education variation across firms is too small to capture the non-linearity in the returns to education clearly shown by the earnings function.

It could be argued that this finding from the earnings function, of a rising return to human capital with its level, resolves the puzzle, identified in the introduction, as to how an economy with relatively scarce skilled labour has a low return on education. The average return is low. However it is so non-linear that for those with skills from secondary school and beyond the returns are very high. Insofar as these skills are those used intensively in a successful manufacturing sector the relative scarcity of such skills is consistent with the failure of Africa to develop a successful manufacturing sector.

Out third question concerned the returns on physical capital. Across all the countries these returns are far higher than those available from human capital investments measured in the production function. Given the very low investment rates in the manufacturing sectors of these 
countries such high returns must also imply high capital costs facing the firms. This finding suggests that the failure of Africa to develop a successful manufacturing sector may have its source, not simply in the market for skills, but also in the costs of capital faced by firms in the African manufacturing sector.

Finally we turn to our fourth question: what is the relative importance of technology and human and physical capital in the determination of productivity and earnings differentials across the countries? For three of the countries, the Cameroon, Kenya and Zimbabwe, technology plays no role. The very large productivity differentials which characterise the Cameroon and Ghanaian manufacturing sectors are due, virtually entirely, to differences in endowments of physical capital, differences in human capital endowment are of negligible importance. 


\section{References}

Appleton, S., Hoddinott, J. and J. Mackinnon (1996) "Education and health in sub-Saharan Africa, Journal of International Development, Vol. 8, No.3, May-June, pp.307-339.

Behrman, J., M.R. Rosenzweig and P. Taubman (1996) "College choice and wages: estimates using data on female twins", Review of Economics and Statistics, Vol. 78, (4), November, pp. 672-685.

Behrman, J. and B. Wolfe (1983) "The socio-economic impact of schooling in a developing country", Review of Economics and Statistics, 66 (2), 296-303.

Bennell, P. (1996) "Rates of return to education: does the conventional pattern prevail in subSaharan Africa" World Development, Vol.24, No. 1, pp. 183-199.

Bigsten A., P. Collier, S. Dercon, B. Gauthier, J. W. Gunning, A. Isaksson, A.Oduro, R. Oostendorp, C. Pattillo, M. Soderbom, M. Sylvain, F. Teal, A. Zeufack (1998) "Investment in Africa's Manufacturing Sector: a Four Country Panel Data Analysis “, CSAE, Oxford, mimeo. Fallon, P.R. and Layard, P.R.G. (1975) "Capital-skill complementarity, income distribution and output accounting", Journal of Political Economy, Vol. 83, No.2, 279-296.

Freeman, R. (1986) "Demand for Education", chapter 6 in O. Ashenfelter and R. Layard (eds.) Handbook of Labor Economics, North-Holland, Amsterdam.

Glewwe, P. (1996) "The relevance of standard estimates of rates of return to schooling for education policy: A critical assessment", Journal of Development Economics, Vol. 51, pp.267290.

Halvorsen, R. And R. Palmquist (1980) "The interpretation of dummy variables in semilogarithmic equations", American Economic Review, Vo.70, No.3, 474-475.

Heckman, J J and V J Hotz (1986) "An investigation of the labour market earnings of Panamanian males: evaluating the sources of inequality", Journal of Human Resources, 21, 507-542.

Jones, P. (1994) “Are manufacturing workers really worth their pay?" CSAE Working paper 942, Oxford, Oxford university.

G. Kingdon (1997) "Does the labour market explain lower female schooling in India", The Development Economics Research Programme, Discussion paper No 1, January.

Knight, J.B. and R.H. Sabot (1990) Education, Productivity and Inequality: The East African Natural Experiment, Oxford University Press.

Knight, J., Song,L. And J. Huaibin (1997) Chinese rural migrants in urban enterprises: three perspectives, Applied economics Discussion Paper No. 190, January, Institute of Economics and Statistics, University of Oxford.

Krishnan, P. (1996) "Family background, education and employment in urban Ethiopia", Oxford Bulletin of Economics and Statistics, 58, 1, pp.167-183.

Krueger, A. (1968) "Factor endowments and per capita income differences among countries", Economic Journal, September 1968, pp.641-659.

Lan, D. and R F Schoeni (1993) "Effects of family background on earnings and returns to schooling: evidence from Brazil", Journal of Political Economy, 101.

Lucas, R.E. Jr (1988) "On the mechanics of economic development", Journal of Monetary Economics, Vol. 22, July, pp.3-42.

Lucas, R.E. Jr (1990) “Why doesn't capital flow from rich to poor countries?", American Economic Review, Vol. 80, May, pp.92-96.

Mincer J. (1974) Schooling, Experience and Earnings, NBER, New York.

Owens, T. and A. Wood (1997) "Export Oriented Industrialisation through Primary Processing?", World Development, 25 (9), September, 1453-1470. 
Psacharopoulos, G. (1994) "Returns to education: a global update", World Development, Vol.22, No.9, pp.1325-1343.

Romer, D. (1996) Advanced Macroeconomics, McGraw-Hill, New York.

White, H. (1980) "A heteroscedasticity-consistent covariance matrix estimator and a direct test for heteroscedasticity", Econometrica, 48, 817-838.

Wood, A. (1994) North-South Trade, Employment and Inequality: Changing fortunes in a skilldriven world, Clarendon Press, Oxford.

Wood, A. and K. Berge (1997) "Exporting Manufactures: Human Resources, Natural Resources, and Trade Policy", Journal of Development Studies, 34 (1), 35-59. 
Table 1 Monthly Earnings (Earnings includes allowances)

\begin{tabular}{|c|c|c|c|c|}
\hline & Round 1 & Round 2 & Round 3 & Average \\
\hline $\begin{array}{l}\text { Cameroon } \\
1993-1995\end{array}$ & 675 & 571 & 409 & 1,655 \\
\hline US \$ & 378 & 202 & 239 & 283 \\
\hline US PPP \$ & 470 & 535 & 367 & 467 \\
\hline CFA francs & 106,937 & 111,986 & 119,407 & 111,761 \\
\hline CFA francs (1990) & 110,472 & 84,852 & 80,139 & 91,821 \\
\hline $\begin{array}{l}\text { Ghana } \\
\text { 1992-1994 }\end{array}$ & 684 & 743 & 1,130 & 2,557 \\
\hline US\$ & 64 & 57 & 41 & 52 \\
\hline US PPP \$ & 172 & 184 & 160 & 170 \\
\hline Cedis & 27,987 & 37,017 & 39,415 & 35,661 \\
\hline Cedis (1990) & 21,545 & 22,808 & 19,445 & 21,266 \\
\hline $\begin{array}{ll}\text { Kenya } & \text { N } \\
1993-1995(a) & \end{array}$ & 1,098 & 972 & 1,063 & 3,133 \\
\hline US \$ & 67 & 75 & 121 & 88 \\
\hline US PPP \$ & 312 & 269 & 413 & 333 \\
\hline Shillings & 3,878 & 4,222 & 6,230 & 4,782 \\
\hline Shillings (1990) & 1,714 & 1,446 & 2,117 & 1,759 \\
\hline $\begin{array}{ll}\text { Zambia } & N \\
1993-1995(a) & \end{array}$ & 903 & 864 & 704 & 2,471 \\
\hline US \$ & 163 & 128 & 123 & 139 \\
\hline US PPP \$ & 194 & 180 & 147 & 176 \\
\hline Kwacha & 70,886 & 98,318 & 102,270 & 89,419 \\
\hline Kwacha (1990) & 4,282 & 3,702 & 3,024 & 3,669 \\
\hline $\begin{array}{ll}\text { Zimbabwe } & \mathrm{N} \\
1993-1994 & \end{array}$ & 1,408 & 552 & na & 1960 \\
\hline US\$ & 145 & 140 & na & 143 \\
\hline US PPP \$ & 326 & 332 & & 328 \\
\hline Zimbabwe \$ & 935 & 1,143 & na & 994 \\
\hline Zimbabwe \$ (1990) & 418 & 418 & na & 418 \\
\hline
\end{tabular}

$\mathrm{N}$ is the number of observations.

(a) For both Kenya and Zambia allowances were not collected for the first round of the surveys. The wage figures have been scaled up by the ratio of wages to allowances for later years to ensure that the data are as comparable as possible across the rounds of the surveys.

\begin{tabular}{lccl}
\hline Average Earnings Chinese Rural Workers (1995) & & \\
& Yuan per year & US\$ per month & US PPP \$ per month \\
Managerial and technical staff & 8,120 & 81 & 395 \\
Production workers & 6,589 & 66 & 320 \\
Total & 6,877 & 69 & 334 \\
Source: Knight and Song (1997). & & & \\
\hline
\end{tabular}


Table 2 Earnings (monthly in US PPP \$) and Formal and Actual Education (in years) (a)

\begin{tabular}{|c|c|c|c|c|c|}
\hline & Cameroon & Ghana & Kenya & Zambia & Zimbabwe \\
\hline $\begin{array}{l}\text { University } \\
\text { Completed }\end{array}$ & 130 & 40 & 59 & 107 & 33 \\
\hline Formal Education & 19 & 19 & 16 & 16 & 16 \\
\hline Actual Education & 19.4 & 19 & 17.7 & 15.8 & 16.5 \\
\hline Earnings & 1,115 & 573 & 1,261 & 694 & 1,302 \\
\hline $\begin{array}{l}\text { Secondary } \quad \mathrm{N} \\
\text { Completed }\end{array}$ & 723 & 524 & 1,215 & 899 & 651 \\
\hline Formal Education & 15.5 & 14.6 & 11.5 & 12.8 & 11.2 \\
\hline Actual Education & 15.5 & 13.5 & 14.1 & 13.9 & 12.3 \\
\hline Earnings & 522 & 211 & 384 & 239 & 402 \\
\hline $\begin{array}{l}\text { Primary } \quad \mathrm{N} \\
\text { Competed }\end{array}$ & 674 & 1,838 & 1,384 & 1,244 & 959 \\
\hline Formal Education & 7.3 & 10.1 & 8 & 8.7 & 8 \\
\hline Actual Education & 8.3 & 10.9 & 9.2 & 9.9 & 10 \\
\hline Earnings & 326 & 155 & 276 & 104 & 267 \\
\hline $\begin{array}{l}\text { Primary N } \\
\text { not competed (b) }\end{array}$ & 128 & 155 & 475 & 221 & 317 \\
\hline Formal Education & 2.1 & 0 & 4.2 & 3.6 & 4.4 \\
\hline Actual Education & 2.6 & na & 5.1 & 4.1 & 9.4 \\
\hline Earnings & 241 & 111 & 254 & 70 & 257 \\
\hline Average & 1655 & 2557 & 3133 & 2471 & 1960 \\
\hline Formal Education & 11.2 & 10.6 & 8.9 & 10.0 & 8.6 \\
\hline Actual Education & 11.6 & 10.9 & 10.6 & 11.1 & 9.5 \\
\hline Earnings & 467 & 170 & 333 & 176 & 328 \\
\hline
\end{tabular}

(a) Formal years of education are calculated from the answers in the questionnaire designed to show the number of years of education. Where both level reached and form reached were available both sources of information were used. In some countries additional information is available on vocational and professional training but the above classification is the most complete that is available for all the countries. The formal education system in each country imply the following for the years it should take to complete each stage. Cameroon: Primary 6 years, Middle School 4 years, Secondary 4 years, lycee 2 years, lycee technique 3 years, I.U.T. 4 years, University 5 years. Ghana: Primary 6 years, Middle 4 years, Secondary 4 years, Vocational 1 year, Polytechnic 2 years, Professional 2 years, University 3 years. Kenya, Zambia and Zimbabwe: Primary 7 years, Secondary 6 years, University 3 years. The actual years are calculated from the answer to the question as to when the worker finished full time education. It was assumed they had begun at 6 years so this figure is in fact a maximum of the number of years as it is known that many children start late and that they may leave the educational system for some years.

(b) In the case of Ghana the number of years attended school for those who did not complete primary education is not available. 
Table 3 Firm Size (Number of Employees), Value-added/Capital, Capital per Employee ( in US PPP \$), Value-added per Employee (in US PPP \$), Education, Tenure (in years) and Monthly Earnings (in US PPP \$) by Country

\begin{tabular}{|c|c|c|c|c|c|c|}
\hline & & Cameroon & Ghana & Kenya & Zambia & Zimbabwe \\
\hline$\underline{\mathrm{N}}$ & & 170 & 230 & 199 & 98 & 261 \\
\hline Employment & Mean & 82 & 42 & 75 & 45 & 300 \\
\hline & Median & 25 & 17 & 30 & 19 & 110 \\
\hline & Std & 197 & 77 & 138 & 72 & 534 \\
\hline Value-added/ & Mean & 1.2 & 3.8 & 2.4 & 2.3 & 1.7 \\
\hline Capital & Median & 0.6 & 1.0 & 0.6 & 0.5 & 0.8 \\
\hline & Std & 2.4 & 9.2 & 6.7 & 5.6 & 4.8 \\
\hline Capital/ & Mean & 19,854 & 5,585 & 18,593 & 17,023 & 21,000 \\
\hline Employee & Median & 8,758 & 629 & 7,242 & 5,426 & 9,299 \\
\hline & Std & 26,319 & 12,565 & 28,490 & 29,409 & 36,695 \\
\hline Value-added/ & Mean & 14,335 & 4,868 & 24,101 & 4,706 & 14,373 \\
\hline Employee & Median & 8,214 & 2,203 & 7,796 & 2,465 & 7,764 \\
\hline & Std & 19,994 & 7,171 & 87,263 & 6,271 & 36,185 \\
\hline Education/ & Mean & 9.7 & 9.3 & 7.9 & 8.6 & 8.2 \\
\hline Employee & Median & 9.5 & 9.6 & 7.9 & 8.5 & 8.3 \\
\hline (years) & Std & 2.4 & 2.2 & 1.9 & 1.9 & 1.3 \\
\hline Tenure/ & Mean & 5.4 & 4.2 & 7.4 & 5.8 & 9.2 \\
\hline Employee & Median & 5.0 & 3.3 & 7.0 & 4.9 & 9.3 \\
\hline (years) & Std & 3.3 & 3.6 & 4.2 & 3.8 & 4.3 \\
\hline$\underline{\mathrm{N}}$ & & 136 & 203 & 188 & 89 & 214 \\
\hline Primary & Mean & 0.44 & 0.78 & 0.43 & 0.55 & 0.49 \\
\hline Completed & Std & 0.33 & 0.26 & 0.29 & 0.32 & 0.26 \\
\hline Secondary & Mean & 0.39 & 0.16 & 0.36 & 0.31 & 0.33 \\
\hline Completed & Std & 0.32 & 0.24 & 0.28 & 0.30 & 0.26 \\
\hline University & Mean & 0.07 & 0.01 & 0.01 & 0.02 & 0.01 \\
\hline Completed & Std & 0.13 & 0.03 & 0.04 & 0.07 & 0.06 \\
\hline$\underline{\mathrm{N}}$ & & 116 & 191 & 182 & 83 & 88 \\
\hline Monthly & Mean & 369 & 170 & 389 & 162 & 440 \\
\hline Earnings & Median & 284 & 130 & 274 & 117 & 311 \\
\hline & Std & 292 & 127 & 374 & 125 & 410 \\
\hline
\end{tabular}

Std is the standard deviation, $\mathrm{N}$ is the number of observations 
Table 4 An Earnings Function Across the Countries: Human Capital Variables Only

\begin{tabular}{|c|c|c|c|c|c|}
\hline \multirow{3}{*}{ Constant } & Cameroon & Ghana & Kenya & Zambia & Zimbabwe \\
\hline & 7.8 & 5.1 & 6.5 & 7.9 & 2.6 \\
\hline & {$[23.0]^{* *}$} & {$[27.2]^{* *}$} & {$[36.2]^{* *}$} & {$[37.4]^{* *}$} & {$[11.3]^{* *}$} \\
\hline \multirow[t]{2}{*}{ Male } & 0.02 & -0.02 & 0.06 & 0.008 & 0.21 \\
\hline & {$[0.6]$} & {$[0.5]$} & [1.9] & {$[0.2]$} & {$[5.1]^{* *}$} \\
\hline \multirow[t]{2}{*}{ Age } & 0.12 & 0.22 & 0.05 & 0.08 & 0.16 \\
\hline & {$[6.3]^{* *}$} & {$[22.4]^{* *}$} & {$[4.8]^{* *}$} & {$[6.0]^{* *}$} & {$[13.0]^{* *}$} \\
\hline \multirow[t]{2}{*}{$\mathrm{Age}^{2}$} & -0.001 & -0.002 & -0.0005 & -0.001 & -0.002 \\
\hline & {$[4.5]^{* *}$} & {$[18.5]^{* *}$} & {$[3.5]^{* *}$} & {$[4.6]^{* *}$} & {$[11.6]^{* *}$} \\
\hline Primary & 0.20 & 0.25 & 0.17 & 0.36 & 0.15 \\
\hline Completed & {$[4.1]^{* *}$} & {$[3.9]^{* *}$} & {$[5.6]^{* *}$} & {$[5.6]^{* *}$} & {$[3.6]^{* *}$} \\
\hline Secondary & 0.72 & 0.57 & 0.44 & 1.0 & 0.77 \\
\hline Completed & {$[14.2]^{* *}$} & {$[8.2]^{* *}$} & {$[12.9]^{* *}$} & {$[14.5]^{* *}$} & {$[13.0]^{* *}$} \\
\hline University & 1.57 & 1.40 & 1.51 & 2.13 & 1.79 \\
\hline Completed & {$[22.3]^{* *}$} & {$[12.7]^{* *}$} & {$[13.1]^{* *}$} & {$[20.8]^{* *}$} & {$[10.5]^{* *}$} \\
\hline \multirow[t]{2}{*}{ Tenure } & 0.03 & 0.02 & 0.003 & 0.04 & 0.01 \\
\hline & {$[5.2]^{* *}$} & {$[2.5]^{*}$} & {$[0.6]$} & {$[5.2]^{* *}$} & {$[2.3]^{*}$} \\
\hline \multirow[t]{2}{*}{ Tenure $^{2}$} & -0.0004 & -0.0003 & 0.0001 & -0.001 & -0.0001 \\
\hline & [1.6] & [1.1] & {$[0.9]$} & {$[3.9]^{* *}$} & {$[0.2]$} \\
\hline \multirow[t]{2}{*}{ Wave 2} & -0.08 & 0.28 & 0.16 & 0.29 & 0.20 \\
\hline & {$[2.5]^{*}$} & {$[6.7]^{* *}$} & {$[5.8]^{* *}$} & {$[8.3]^{* *}$} & {$[6.2]^{* *}$} \\
\hline \multirow{2}{*}{ Wave 3} & -0.07 & 0.35 & 0.43 & 0.61 & \\
\hline & {$[2.1]^{*}$} & {$[8.5]^{* *}$} & {$[16.1]^{* *}$} & {$[15.7]^{* *}$} & \\
\hline Adjusted $\mathrm{R}^{2}$ & 0.47 & 0.46 & 0.22 & 0.39 & 0.28 \\
\hline $\mathrm{N}$ & 1655 & 2557 & 3133 & 2471 & 1960 \\
\hline White $\chi^{2}$ test & $93(53)$ & $209(54)$ & $136(53)$ & $124(53)$ & $145(44)$ \\
\hline
\end{tabular}

The figures in [ ] parentheses are t statistics using White (1980) corrected standard errors.* indicates significance at the 5 per level, $* *$ at the 1 per cent level.

Rates of Inflation

$(\%$ pa) $\mathrm{A} *$ indicates that it is the period to which the wave dummy in the regression refers.

$\begin{array}{llllll}1992 / 93 & -3.3 & 24.9^{*} & 45.8 & 189 & 27.6 \\ 1992 / 94 & 30.8 & 56.0^{*} & 88.0 & 340 & 56.0 \\ 1993 / 94 & 35.1^{*} & 24.9 & 29.0^{*} & 52.3^{*} & 22.2^{*} \\ 1993 / 95 & 53.9^{*} & 118 & 30.0^{*} & 104^{*} & 49.9\end{array}$

Change in real wages over survey period

$\begin{array}{lllll}-40 & -9 & 18 & -10 & 0\end{array}$


Table 5 Increment in Earnings (\%) and Rates of Return (\% pa) to Human Capital Cameroon Ghana Kenya Zambia Zimbabwe

Education

Primary Completers

Increment in Earning

Years 7

Rate of return $\quad 3$

$28 \quad 19$

$19 \quad 43 \quad 16$

$\begin{array}{llll}10 & 8 & 9 & 8\end{array}$

Secondary Completers

Increment in Earning

Years

$68 \quad 38$

$38 \quad 31$

$31 \quad 90$

$90 \quad 86$

Rate of return

8

15

6

4

3

522

27

University Completers

Increment in Earning

Years

$134 \quad 129$

$129 \quad 192$

209

177

Rate of return

4

4

29

5

3

5

38

43

65

37

Weighted Rate

of Return

85

4

12

12

Age

Primary Completers

\begin{tabular}{|c|c|c|c|c|c|}
\hline Age & 0.07 & 0.24 & 0.04 & 0.07 & 0.12 \\
\hline & 3.6 & {$[22.5]$} & [3.1] & {$[5.3]$} & {$[8.3]$} \\
\hline $\mathrm{Age}^{2}$ & -0.0005 & -0.003 & -0.0004 & -0.0008 & -0.001 \\
\hline & [1.9] & [18.5] & {$[2.3]$} & [4.3] & [7.6] \\
\hline Rate of Return & 4 & 5 & 1 & 1 & 5 \\
\hline Secondary Com & & & & & \\
\hline Age & 0.18 & 0.22 & 0.04 & 0.14 & 0.18 \\
\hline & [6.9] & {$[10.7]$} & {$[2.0]$} & [5.7] & [6.1] \\
\hline $\mathrm{Age}^{2}$ & -0.002 & -0.002 & -0.0001 & -0.001 & -0.002 \\
\hline & {$[5.1]$} & [8.1] & {$[0.3]$} & [4.2] & [4.1] \\
\hline Rate of Return & 4 & 8 & 3 & 7 & 6 \\
\hline University Com & & & & & \\
\hline Age & 0.35 & 0.02 & 0.45 & 0.23 & 0.33 \\
\hline & {$[5.2]$} & {$[0.2]$} & {$[3.1]$} & [2.9] & [1.98] \\
\hline $\mathrm{Age}^{2}$ & -0.004 & 0.0 & -0.006 & -0.003 & -0.004 \\
\hline & {$[4.4]$} & {$[0.02]$} & {$[3.1]$} & [2.6] & {$[1.7]$} \\
\hline Rate of Return & 8 & na & 18 & 9 & 8 \\
\hline $\begin{array}{l}\text { Weighted Rate } \\
\text { of Return }\end{array}$ & 4 & 6 & 2 & 3 & 5 \\
\hline
\end{tabular}


Table 6 Production Functions Across the Countries

IV Estimates with Lagged Values of Physical Capital and Education

Dependent variable: Ln (Value-added) (a)

\begin{tabular}{|c|c|c|c|c|c|}
\hline & Cameroon & Ghana & Kenya & Zambia & Zimbabwe \\
\hline Constant & $\begin{array}{l}8.5 \\
{[6.9]^{* *}}\end{array}$ & $\begin{array}{l}8.40 \\
{[14.0]^{* *}}\end{array}$ & $\begin{array}{l}6.03 \\
{[9.0]^{* *}}\end{array}$ & $\begin{array}{l}10.4 \\
{[8.5]^{* *}}\end{array}$ & $\begin{array}{l}4.54 \\
{[7.5]^{* *}}\end{array}$ \\
\hline Ln (Employment $)_{\mathrm{t}}$ & $\begin{array}{l}0.25 \\
{[0.8]}\end{array}$ & $\begin{array}{l}0.63 \\
{[2.6]^{* *}}\end{array}$ & $\begin{array}{r}0.16 \\
{[0.7]}\end{array}$ & $\begin{array}{l}0.57 \\
{[2.5]^{*}}\end{array}$ & $\begin{array}{l}0.13 \\
{[0.5]}\end{array}$ \\
\hline $\begin{array}{l}\text { Ln } \text { (Physical } \\
\text { Capital) }_{(\mathrm{t}-1)}\end{array}$ & $\begin{array}{l}0.32 \\
{[4.7]^{* *}}\end{array}$ & $\begin{array}{l}0.32 \\
{[8.2]^{* *}}\end{array}$ & $\begin{array}{l}0.36 \\
{[6.9]^{* *}}\end{array}$ & $\begin{array}{l}0.20 \\
{[2.7]^{* *}}\end{array}$ & $\begin{array}{l}0.44 \\
{[11.1]^{* *}}\end{array}$ \\
\hline Ln (Education) $)_{(\mathrm{t}-1)}$ & $\begin{array}{l}0.43 \\
{[1.5]}\end{array}$ & $\begin{array}{l}0.04 \\
{[0.2]}\end{array}$ & $\begin{array}{l}0.48 \\
{[2.0]^{*}}\end{array}$ & $\begin{array}{l}0.23 \\
{[1.1]}\end{array}$ & $\begin{array}{l}0.43 \\
{[1.7]}\end{array}$ \\
\hline Round Dummy & $\begin{array}{l}-0.16 \\
{[0.9]}\end{array}$ & $\begin{array}{l}0.11 \\
{[0.7]}\end{array}$ & $\begin{array}{l}0.14 \\
{[0.8]}\end{array}$ & $\begin{array}{l}0.18 \\
{[0.7]}\end{array}$ & $\begin{array}{l}0.13 \\
{[1.3]}\end{array}$ \\
\hline $\begin{array}{l}\text { Adjusted } \mathrm{R}^{2} \\
\mathrm{~N}\end{array}$ & $\begin{array}{l}0.81 \\
170\end{array}$ & $\begin{array}{l}0.70 \\
230\end{array}$ & $\begin{array}{l}0.79 \\
199\end{array}$ & $\begin{array}{l}0.67 \\
98\end{array}$ & $\begin{array}{l}0.88 \\
261\end{array}$ \\
\hline $\begin{array}{l}\text { Test of Cobb- } \\
\text { Douglas (b) }\end{array}$ & $\begin{array}{l}18.5 \\
{[0.7]}\end{array}$ & $\begin{array}{l}9.3 \\
{[0.3]}\end{array}$ & $\begin{array}{l}21.3 \\
{[0.9]}\end{array}$ & $\begin{array}{l}18.2 \\
{[0.7]}\end{array}$ & $\begin{array}{l}9.1 \\
{[0.5]}\end{array}$ \\
\hline $\begin{array}{l}\text { Test of Constant } \\
\text { Returns to Scale (b) }\end{array}$ & $\begin{array}{l}59.2 \\
{[4.0]^{* *}}\end{array}$ & $\begin{array}{l}3.1 \\
{[0.3]}\end{array}$ & $\begin{array}{l}17.5 \\
{[1.5]}\end{array}$ & $\begin{array}{l}0.1 \\
{[0.9]}\end{array}$ & $\begin{array}{l}37.5 \\
{[2.4]^{*}}\end{array}$ \\
\hline
\end{tabular}

The figures in [ ] parentheses are t statistics. * indicates significance at the 5 per level, ** at the 1 per cent level.

(a) The controls included in this equation are for location, sector and ownership. The employment variable is instrumented by lagged employment. (b) These are Lagrange multiplier (LM) tests implemented in SAS. The figures in [ ] are $t$ tests of the hypothesis that the LM is zero.

Rates of return (\% pa)

Physical capital 19

32

22

10

35

Education

4

1

6

3

9 
Table 7 Production Functions Across the Countries

IV Estimates with Lagged Values of Physical and Human Capital (Education + Tenure)

Dependent variable: $\mathrm{Ln}$ (Value-added) (a)

\begin{tabular}{|c|c|c|c|c|c|}
\hline & Cameroon & Ghana & Kenya & Zambia & Zimbabwe \\
\hline Constant & $\begin{array}{l}8.9 \\
{[8.9]^{* *}}\end{array}$ & $\begin{array}{l}8.34 \\
{[18.3]}\end{array}$ & $\begin{array}{l}6.40 \\
{[10.5]}\end{array}$ & $\begin{array}{l}10.6 \\
{[9.6]}\end{array}$ & $\begin{array}{l}4.8 \\
{[10.2]}\end{array}$ \\
\hline Ln (Employment $)_{t}$ & $\begin{array}{l}0.14 \\
{[0.6]}\end{array}$ & $\begin{array}{l}0.16 \\
{[1.1]}\end{array}$ & $\begin{array}{l}0.31 \\
{[1.7]}\end{array}$ & $\begin{array}{l}0.59 \\
{[3.4]^{* *}}\end{array}$ & $\begin{array}{c}0.18 \\
{[0.9]}\end{array}$ \\
\hline $\begin{array}{l}\text { Ln } \text { (Physical } \\
\text { Capital) }_{(\mathrm{t}-1)}\end{array}$ & $\begin{array}{l}0.28 \\
{[4.2]^{* *}}\end{array}$ & $\begin{array}{l}0.28 \\
{[6.6]^{* *}}\end{array}$ & $\begin{array}{l}0.35 \\
{[6.7]^{* *}}\end{array}$ & $\begin{array}{l}0.19 \\
{[2.6]^{*}}\end{array}$ & $\begin{array}{l}0.42 \\
{[10.4]^{* *}}\end{array}$ \\
\hline $\begin{array}{l}\text { Ln }(\text { Education })_{(\mathrm{t}-1)} \\
+\mathrm{Ln} \text { (Tenure) }_{(\mathrm{t}-1)}\end{array}$ & $\begin{array}{l}0.29 \\
{[2.3]^{*}}\end{array}$ & $\begin{array}{l}0.28 \\
{[3.5]^{* *}}\end{array}$ & $\begin{array}{l}0.17 \\
{[1.7]}\end{array}$ & $\begin{array}{l}0.11 \\
{[1.3]}\end{array}$ & $\begin{array}{l}0.20 \\
{[1.9]}\end{array}$ \\
\hline Round Dummy & $\begin{array}{l}-0.15 \\
{[0.8]}\end{array}$ & $\begin{array}{l}0.03 \\
{[0.2]}\end{array}$ & $\begin{array}{l}0.19 \\
{[1.2]}\end{array}$ & $\begin{array}{l}0.17 \\
{[0.7]}\end{array}$ & $\begin{array}{l}0.12 \\
{[1.5]}\end{array}$ \\
\hline $\begin{array}{l}\text { Adjusted } \mathrm{R}^{2} \\
\mathrm{~N}\end{array}$ & $\begin{array}{l}0.79 \\
170\end{array}$ & $\begin{array}{l}0.71 \\
230\end{array}$ & $\begin{array}{l}0.79 \\
199\end{array}$ & $\begin{array}{l}0.67 \\
98\end{array}$ & $\begin{array}{l}0.88 \\
261\end{array}$ \\
\hline $\begin{array}{l}\text { Test of Cobb- } \\
\text { Douglas (b) }\end{array}$ & $\begin{array}{l}2.1 \\
{[0.2]}\end{array}$ & $\begin{array}{l}44.2 \\
{[0.7]}\end{array}$ & $\begin{array}{l}24.8 \\
{[0.9]}\end{array}$ & $\begin{array}{l}37.9 \\
{[0.7]}\end{array}$ & $\begin{array}{l}3.1 \\
{[0.1]}\end{array}$ \\
\hline $\begin{array}{l}\text { Test of Constant } \\
\text { Returns to Scale (b) }\end{array}$ & $\begin{array}{l}51.2 \\
{[3.6]^{* *}}\end{array}$ & $\begin{array}{l}26.6 \\
{[1.9]}\end{array}$ & $\begin{array}{l}24.5 \\
{[1.9]}\end{array}$ & $\begin{array}{l}1.4 \\
{[0.4]}\end{array}$ & $\begin{array}{l}31.8 \\
{[2.1]^{*}}\end{array}$ \\
\hline $\begin{array}{l}\text { Test of Restriction } \\
\text { on human capital (b) }\end{array}$ & $\begin{array}{l}0.11 \\
{[0.1]}\end{array}$ & $\begin{array}{l}5.1 \\
{[4.4]}\end{array}$ & $\begin{array}{l}4.9 \\
{[1.2]}\end{array}$ & $\begin{array}{l}0.54 \\
{[0.2]}\end{array}$ & $\begin{array}{l}3.8 \\
{[2.6]}\end{array}$ \\
\hline
\end{tabular}

The figures in [ ] parentheses are t statistics. * indicates significance at the 5 per level, $* *$ at the 1 per cent level.

(a) The controls included in this equation are for location, sector and ownership. The employment variable is instrumented by lagged employment. (b) These are Lagrange multiplier (LM) tests implemented in SAS. The figures in [ ] are $t$ tests of the hypothesis that the LM is zero.

\begin{tabular}{lccccc}
\hline Rates of return (\%pa) & & & & & \\
Physical capital & 17 & 28 & 21 & 10 & 34 \\
Human capital & 4 & 4 & 2 & 2 & 2 \\
\hline
\end{tabular}


Table 8 Pooled Regressions for Earnings across Five African Countries

Dependent Variable Ln (Earnings in US PPP \$)

\begin{tabular}{|c|c|c|}
\hline Constant & $\begin{array}{l}\text { No controls } \\
{[1]} \\
1.94 \\
{[19.7]^{* *}}\end{array}$ & $\begin{array}{l}\text { Controls (a) } \\
{[2]} \\
1.66 \\
{[9.9]^{* *}}\end{array}$ \\
\hline $\begin{array}{l}\text { Primary } \\
\text { Completed }_{t-1}\end{array}$ & $\begin{array}{l}0.25 \\
{[11.5]^{* *}}\end{array}$ & $\begin{array}{l}0.17 \\
{[7.9]^{* *}}\end{array}$ \\
\hline $\begin{array}{l}\text { Secondary } \\
\text { Completed }_{t-1}\end{array}$ & $\begin{array}{l}0.69 \\
{[29.4]^{* *}}\end{array}$ & $\begin{array}{l}0.49 \\
{[20.5]^{* *}}\end{array}$ \\
\hline $\begin{array}{l}\text { University } \\
\text { Completed }_{t-1}\end{array}$ & $\begin{array}{l}1.69 \\
{[36.9]^{* *}}\end{array}$ & $\begin{array}{l}1.36 \\
{[25.2]^{* *}}\end{array}$ \\
\hline $\begin{array}{l}\operatorname{Age}_{t-1} \\
\operatorname{Age}_{t-1}^{2}\end{array}$ & $\begin{array}{l}0.14 \\
{[26.1]^{* *}} \\
-0.002 \\
{[20.5]^{* *}}\end{array}$ & $\begin{array}{l}0.11 \\
{[19.9]^{* *}} \\
-0.001 \\
{[16.1]^{* *}}\end{array}$ \\
\hline $\begin{array}{l}\text { Tenure }_{t-1} \\
\text { Tenure }_{t-1}^{2}\end{array}$ & $\begin{array}{l}0.01 \\
{[4.2]^{* *}} \\
0.0 \\
{[0.6]}\end{array}$ & $\begin{array}{l}-0.001 \\
{[0.1]} \\
0.0002 \\
{[1.6]}\end{array}$ \\
\hline Round 2 & $\begin{array}{l}-0.02 \\
{[1.3]}\end{array}$ & $\begin{array}{l}0.006 \\
{[0.3]}\end{array}$ \\
\hline Round 3 & $\begin{array}{l}-0.01 \\
{[0.6]}\end{array}$ & $\begin{array}{l}0.03 \\
{[1.5]}\end{array}$ \\
\hline Cameroon & $\begin{array}{l}0.23 \\
{[9.9]^{* *}}\end{array}$ & $\begin{array}{l}0.23 \\
{[9.5]^{* *}}\end{array}$ \\
\hline Ghana & $\begin{array}{l}-0.44 \\
{[19.8]^{* *}}\end{array}$ & $\begin{array}{l}-0.45 \\
{[17.1]^{* *}}\end{array}$ \\
\hline Kenya & $\begin{array}{l}0.10 \\
{[5.0]^{* *}}\end{array}$ & $\begin{array}{l}0.14 \\
{[6.6]^{* *}}\end{array}$ \\
\hline Zambia & $\begin{array}{l}-1.1 \\
{[46.9] * *}\end{array}$ & $\begin{array}{l}-0.91 \\
{[34.8]^{* *}}\end{array}$ \\
\hline $\begin{array}{l}\text { Adjusted } \mathrm{R}^{2} \\
\mathrm{~N} \\
\text { White test } \chi^{2}(\mathrm{df})\end{array}$ & $\begin{array}{l}0.49 \\
11,776 \\
510(98)\end{array}$ & $\begin{array}{l}0.52 \\
9,417 \\
872(292)\end{array}$ \\
\hline
\end{tabular}

The figures in [ ] parentheses are $\mathrm{t}$ statistics where the standard errors have been corrected by the method due to White (1980). * indicates significance at the 5 per level, ** at the 1 per cent level.

(a) The controls included in this equation are for location, sector and ownership, the capital labour ratio and its square, firm size measured by employment and its square. 
Table 9 Rates of Return from the Earnings Functions (a)

\begin{tabular}{|c|c|c|c|c|c|c|}
\hline & Proportions & $\begin{array}{l}\text { Increment in } \\
{[1]} \\
\text { No controls }\end{array}$ & $\begin{array}{l}\text { rnings } \\
{[2]} \\
\text { Controls }\end{array}$ & $\begin{array}{l}\text { Years of } \\
\text { Education } \\
\text { Is }\end{array}$ & $\begin{array}{l}\text { Rates } \\
\text { of return } \\
\text { no controls }\end{array}$ & $\begin{array}{l}\text { Rates } \\
\text { of return } \\
\text { controls }\end{array}$ \\
\hline $\begin{array}{l}\text { Primary } \\
\text { Completed }\end{array}$ & 0.58 & 28 & 19 & 9 & 3 & 3 \\
\hline $\begin{array}{l}\text { Secondary } \\
\text { Completed }\end{array}$ & 0.38 & 55 & 38 & 13 & 14 & 10 \\
\hline $\begin{array}{l}\text { University } \\
\text { Completed }\end{array}$ & 0.04 & 172 & 139 & 17 & 43 & 35 \\
\hline \multicolumn{5}{|c|}{ Weighted average (b) } & 9 & 7 \\
\hline
\end{tabular}

(a) The increments in earnings are taken from Table 8. [1] refers to the equation with no controls, [2] to the equation with controls for location, sector and ownership, the capital labour ratio and its square, firm size measured by employment and its square.

(b) The weights used are the proportions of each class of completed education across the whole sample. 
Table 10 Pooled Regressions for Value-added across Five African Countries

IV Estimates with Lagged Values of Physical and Human Capital Measures (a)

Dependent Variable

Ln (Value-added in US PPP \$)

\begin{tabular}{|c|c|c|}
\hline \multirow{3}{*}{ Constant } & [1] & [2] \\
\hline & 4.8 & 5.02 \\
\hline & {$[16.9]^{* *}$} & {$[22.3]^{* *}$} \\
\hline \multirow{2}{*}{ Ln (Employment $)_{\mathrm{t}}$} & 0.25 & 0.23 \\
\hline & {$[2.2]^{*}$} & {$[2.9]^{* *}$} \\
\hline Ln (Physical & 0.33 & 0.31 \\
\hline Capital) $_{(\mathrm{t}-1)}$ & {$[15.6]^{* *}$} & {$[14.1]^{* *}$} \\
\hline \multirow[t]{2}{*}{$\operatorname{Ln}(\text { Education })_{(\mathrm{t}-1)}$} & 0.42 & \\
\hline & [3.7] & \\
\hline \multirow{2}{*}{$\begin{array}{l}\text { Ln }(\text { Education })_{(\mathrm{t}-1)} \\
+\operatorname{Ln}(\text { Tenure })_{(\mathrm{t}-1)}\end{array}$} & & 0.23 \\
\hline & & [5.4] \\
\hline \multirow[t]{2}{*}{ Round Dummy } & -0.03 & -0.03 \\
\hline & {$[0.4]$} & {$[0.5]$} \\
\hline \multirow[t]{2}{*}{ Cameroon } & -0.29 & -0.12 \\
\hline & {$[2.6]^{* *}$} & [1.1] \\
\hline \multirow[t]{2}{*}{ Ghana } & -0.40 & -0.22 \\
\hline & {$[3.6]^{* *}$} & {$[1.9]^{*}$} \\
\hline \multirow[t]{2}{*}{ Kenya } & 0.08 & 0.12 \\
\hline & {$[0.8]$} & [1.2] \\
\hline \multirow[t]{2}{*}{ Zambia } & -1.0 & -0.89 \\
\hline & {$[7.6]^{* *}$} & {$[7.0]^{* *}$} \\
\hline \multirow{2}{*}{$\begin{array}{l}\text { Adjusted } \mathrm{R}^{2} \\
\mathrm{~N}\end{array}$} & 0.83 & 0.83 \\
\hline & 958 & 958 \\
\hline Test of Pooling & 2.18 & 1.2 \\
\hline Coefficients (b) & {$[0.6]$} & {$[1.5]$} \\
\hline Test of Constant & 119.3 & 92.6 \\
\hline Returns to Scale (b) & {$[4.1]^{* *}$} & {$[3.1]^{* *}$} \\
\hline
\end{tabular}

The figures in [ ] parentheses are t statistics. $*$ indicates significance at the 5 per level, $* *$ at the 1 per cent level.

(a) The controls included in this equation are for location, sector and ownership. The employment variable is instrumented by lagged employment. (b) These are Lagrange multiplier (LM) tests implemented in SAS. The figures in [ ] are $\mathrm{t}$ tests of the hypothesis that the LM is zero.

Median Value of Value-added to Capital

Median Value of Education/Employee

Median Value of Tenure/Employee

Rates of return (\%pa)

Physical capital

23

Human capital 5 
Table 11 Pooled Regressions for Productivity and Earnings across Five African Countries (a)

\section{Dependent \\ Variable}

\begin{tabular}{|c|c|c|c|c|}
\hline Constant & $\begin{array}{l}5.1 \\
{[18.5]^{* *}}\end{array}$ & $\begin{array}{l}2.9 \\
{[3.9]^{* *}}\end{array}$ & $\begin{array}{l}3.8 \\
{[21.4]^{* *}}\end{array}$ & $\begin{array}{l}1.1 \\
{[1.4]}\end{array}$ \\
\hline $\begin{array}{l}\text { Ln (Physical Capital } \\
\text { per Employee) } \\
(\mathrm{t}-1)\end{array}$ & $\begin{array}{l}0.28 \\
{[11.4]^{* *}}\end{array}$ & $\begin{array}{l}0.29 \\
{[1.5]}\end{array}$ & $\begin{array}{l}0.08 \\
{[5.4]^{* *}}\end{array}$ & $\begin{array}{l}0.19 \\
{[1.3]}\end{array}$ \\
\hline Ln (Human Capital) $)_{(\mathrm{t}-1)}$ & $\begin{array}{l}0.27 \\
{[5.0]^{* *}[1.6]}\end{array}$ & 0.81 & $\begin{array}{l}0.24 \\
{[6.8]^{* *}}\end{array}$ & $\begin{array}{l}0.71 \\
{[1.6]}\end{array}$ \\
\hline Round Dummy & $\begin{array}{l}0.01 \\
{[0.11]}\end{array}$ & & $\begin{array}{l}-0.03 \\
{[0.7]}\end{array}$ & \\
\hline Cameroon & $\begin{array}{l}-0.03 \\
{[0.4]}\end{array}$ & & $\begin{array}{l}-0.16 \\
{[1.8]}\end{array}$ & \\
\hline Ghana & $\begin{array}{l}-0.27 \\
{[2.7]^{*}}\end{array}$ & & $\begin{array}{l}-0.64 \\
{[7.6]^{* *}}\end{array}$ & \\
\hline Kenya & $\begin{array}{l}0.15 \\
{[1.54]}\end{array}$ & & $\begin{array}{l}0.02 \\
{[0.2]}\end{array}$ & \\
\hline Zambia & $\begin{array}{l}-0.73 \\
{[5.6]^{* *}}\end{array}$ & & $\begin{array}{l}-0.67 \\
{[7.5]^{* *}}\end{array}$ & \\
\hline Adjusted $\mathrm{R}^{2}$ & 0.44 & 0.59 & 0.52 & 0.53 \\
\hline White $\chi^{2}(\mathrm{df})$ & $97(83)$ & $4(5)$ & $87(82)$ & $4(5)$ \\
\hline $\mathrm{N}$ & 958 & 10 & 660 & 9 \\
\hline
\end{tabular}

Log (Earnings per Employee in US PPP \$)
[1]
[2] (b)
[3]
[4] (b)

.6] Employee in US PPP \$)

The figures in [ ] parentheses are $\mathrm{t}$ statistics where the standard errors have been corrected by the method due to White (1980). * indicates significance at the 5 per level, ** at the 1 per cent level.

(a) The controls included in this equation are for location, sector and ownership.

(b) Equations [2] and [4] are the aggregation over the five countries of the equations estimated on the pooled data. For the productivity equation we have two rounds of the data for five countries so 10 observations, for the earnings function one round of the data is missing so we have 9 observations. 


\section{Data Appendix}

In constructing the variables used in the regressions reported in this paper a range of decisions needed to be taken to construct the data. In this appendix we outline how the variables are constructed.

Value-added: The value of sales less material input costs less indirect costs.

Employment: The total number of employees in the firm at the end of the year.

Physical Capital: The replacement value of the capital stock for plant and equipment.

Human Capital: To create measures of human capital stock for firm level data we began with the individual level data. From interviews with the employees of the firms we knew the years of education, tenure and age by occupational classification. The occupational composition of the firm's workforce was available from the firm level data. We combined these two sources of information to create a weighted average of the three human capital variables, education, tenure and age where the weights were the proportions of the workforce in each occupation. If there was no worker level information for an occupation that existed for the firm we used the averages for that occupational classification to fill in the missing observations. The human capital variable that proved most significant in the production functions over the five countries was an unweighted average of years of education and tenure.

Purchasing Power Parity (PPP) Exchange Rates:

All the nominal values across countries have been made comparable by the use of PPPs. These were updated from the figures given in the PENN world tables. Here we indicate how this was done and give out estimates of the PPPs for each country. The PENN world tables supplies two variables PC and PI which are the PPPs for consumption and investment expenditures respectively, expressed as a percentage of the official exchange rate. These figures end in 1992. We updated both by constructing a real exchange rate series based on the US export price index and the domestic CPI. We then updated the PPP by the change in the real exchange rate. In the case of Zambia we chose 1990 as the base as the PENN data stops for 1991 when radical changes in PI are shown.

$\begin{array}{lllllll} & 1990 & 1991 & 1992 & 1993 & 1994 & 1995 \\ \text { Cameroon } & & & & & & \\ \text { PC (\%) } & 87.7 & 91.6 & 88.7 & 80.3 & 53.9 & 65.2 \\ \text { PI (\%) } & 127.5 & 139.8 & 129.2 & 117.0 & 78.6 & 95.0 \\ \text { Exchange Rate (CFA Francs/US\$) } & 272.3 & 282.1 & 264.7 & 283.2 & 555.2 & 499.2 \\ \text { Ghana } & & & & & & \\ \text { PC (\%) } & 39.8 & 40.1 & 37.0 & 31.1 & 25.8 & 34.1 \\ \text { PI (\%) } & 97.0 & 101.0 & 90.3 & 75.8 & 62.9 & 83.1 \\ \text { Exchange Rate (Cedis/US\$) } & 326.3 & 367.8 & 437.1 & 649.1 & 956.7 & 1200.4 \\ \text { Kenya } & & & & & & \\ \text { PC (\%) } & 30.3 & 26.7 & 26.5 & 21.4 & 27.9 & 29.3 \\ \text { PI (\%) } & 68.6 & 61.2 & 56.2 & 45.4 & 59.1 & 62.1 \\ \text { Exchange Rate (Shillings/US\$) } & 22.9 & 27.5 & 32.2 & 58.0 & 56.1 & 51.4 \\ \text { Zambia } & & & & & & \\ \text { PC (\%) } & 77.5 & 69.3 & 81.3 & 84.2 & 70.9 & 83.4 \\ \text { PI (\%) } & 73.0 & 65.3 & 76.6 & 79.3 & 66.8 & 78.5 \\ \text { Exchange Rate (Kwachas/US\$) } & 28.9 & 61.7 & 156.3 & 434.8 & 769.2 & 833.3 \\ \text { Zimbabwe } & & & & & & \\ \text { PC (\%) } & 56.1 & 47.4 & 44.3 & 44.4 & 42.2 & 46.4 \\ \text { PI (\%) } & 69.0 & 64.1 & 55.5 & 55.6 & 52.9 & 58.1 \\ \text { Exchange Rate (Zimbabwe\$/US\$) } & 2.4 & 3.4 & 5.1 & 6.5 & 8.1 & 8.7\end{array}$

